\title{
Manipulation of the pre-partum diet of dairy cows to promote early adaptation to perennial ryegrass herbage
}

\author{
V.M. Russo ${ }^{1,2,3 \dagger}$, W.J. Wales ${ }^{2,4}$, B.J. Leury ${ }^{3}$, M.C. Hannah², E. Kennedy ${ }^{1}$
}

${ }^{1}$ Teagasc, Animal and Grassland Research and Innovation Centre, Moorepark, Fermoy, Co. Cork, Ireland

${ }^{2}$ Agriculture Victoria Research, Ellinbank, Victoria 3821, Australia

${ }^{3}$ Faculty of Veterinary and Agricultural Sciences, The University of Melbourne, Parkville, Victoria 3010, Australia

${ }^{4}$ Centre for Agricultural Innovation, School of Agriculture and Food, Faculty of Veterinary and Agricultural Sciences, The University of

Melbourne, Victoria 3010, Australia

Abstract

The diet of dairy cows in Ireland traditionally changes abruptly from predominantly pasture silage before calving to grazed perennial ryegrass immediately after calving. This potentially leads to problems with adaptation of microbes in the rumen with consequences of reduced intake and ultimately lower milk production. This experiment aimed to determine if introducing first-lactation dairy cows to perennial ryegrass herbage in the final weeks of pregnancy, thus eliminating a major dietary change at calving, could improve the adaptation process, potentially increasing dry matter intake (DMI) and milk production in early lactation. Three weeks prior to their expected calving date, 14 spring calving dairy cows were assigned to one of two treatments $(n=7)$ : pasture silage pre-partum and perennial ryegrass herbage post-partum, or perennial ryegrass herbage both pre- and post-partum. Treatment diets were fed for 11 ( \pm 7$) d$ pre-partum and for $14( \pm 0) d$ post-partum. For both treatments, DMI increased post-partum, but there was no difference between treatments, pre- or post-partum (5.9 and $8.8 \mathrm{~kg} \mathrm{DM} / \mathrm{cow}$ per day, respectively). There were no differences in milk yield or composition between the treatments. Body condition score declined following parturition but there were no differences between treatments. Plasma non-esterified fatty acids, glucose and $\beta$-hydroxybutyrate were also unaffected by treatment but did indicate a state of negative energy balance in early lactation. The results of this experiment suggest that pre-partum adaptation to perennial ryegrass herbage would not benefit milk production in first-lactation dairy cows in early lactation in Irish dairy farms employing this system.

Keywords

Energy balance $\cdot$ milk production $\cdot$ transition

\section{Introduction}

The Irish dairy industry is a pasture-based production system and success is largely reliant on maximising the annual milk production from grazed pasture (Dillon et al., 1995; Horan et al., 2005; Hanrahan et al., 2018). The use of pasture silage is also pivotal within the industry; however, grazed pasture is cheaper (Finneran et al., 2010) and nutritionally superior (Dillon et al., 2002), providing the incentive for maximising its use. Due to the seasonality of pasture production, most dairy cows in Ireland are housed indoors and fed pasture silage during the non-lactating period. Immediately postpartum, these cows are turned out to graze pasture. When a ruminant's diet is changed in either amount of feeding or composition of diet, the rumen requires time to adapt in order to avoid digestive or metabolic disorders (Kaufmann et al., 1980; Humer et al., 2018). Poor adaptation impacts dry matter
(DM) intake (DMI) (Tremere et al., 1968; Pourazad et al., 2016) and consequently milk yield.

The transition period, typically referred to as $3 \mathrm{wk}$ immediately before and after calving, is recognised as the most challenging time for a dairy cow due to the onset of both parturition and lactation. The difficulties at this time are highlighted by the fact that the risk of disease is greatly increased (Shanks et al., 1981; Curtis et al., 1985). During the transition period, a decline in DMI occurs (Grummer et al., 2004; Douglas et al., 2006) despite rising nutritional demands on the body. Cows in early lactation commonly enter a state of negative energy balance (NEB), where body reserves are mobilised to meet the deficit between energy intake and lactation needs (Bauman \& Currie, 1980). Entering a state of NEB can result in health concerns for the animal, as well as impacting 
long-term milk production. Nutrition during the transition period can affect the production, health and reproductive performance of a cow for the entire lactation (Grummer, 1995; Grummer et al., 2010). Thus, it is recommended to use nutritional strategies during this period to minimise NEB, allowing for an improved metabolic state. An increase in DMI during early lactation can reduce the deficit between energy intake and expenditure, thereby improving energy balance. Irish dairy cows face an abrupt dietary change immediately after calving, exacerbating an already stressful period for the cow, which may result in reduced DMI and subsequent milk yield. Any means of increasing DMI pre-partum can help decrease the incidences of metabolic disease post-partum (Grummer, 1995; Mann et al., 2015). Previous work has shown that introducing cows to pasture in early lactation results in greater $\mathrm{DMI}$ and yields of milk, fat, protein and lactose when compared to offering pasture silage as the sole forage source (Dillon et al., 2002). The objective of this experiment was to determine if offering harvested fresh pasture even earlier, in late pregnancy, and thus adapting cows to the new diet sooner, could improve productivity and health outcomes following the transition period for dairy cows, leading to increased DMI and milk production in early lactation. The hypotheses tested were (1) that cows fed perennial ryegrass herbage pre-partum will have a greater prepartum DMI than cows fed silage pre-partum and (2) that cows adapted to perennial ryegrass herbage pre-partum will have a greater DMI and milk yield post-partum than cows fed silage pre-partum and perennial ryegrass herbage post-partum.

\section{Materials and methods}

The experiment was conducted in late winter through to early spring of 2016 at Teagasc Moorepark Research Centre,

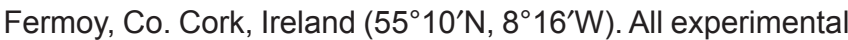
procedures were carried out in accordance with the European Union Directive 2010/63/EU and S.I. No. 516 of 2016.

\section{Experimental design and dietary treatments}

Fourteen spring calving Holstein-Friesian primiparous cows (age $1.9 \mathrm{yr}$; s.d. 0.04) were allocated to one of two groups. Allocation was random, subject to balancing for expected calving date, live weight (503 kg; s.d. 40.3), (body condition score (BCS): 3.21 ; s.d. 0.088, five-point scale) and estimated economic breeding index. Each group was assigned one of two feeding strategies: pasture silage pre-partum followed by harvested perennial ryegrass (Lolium perenne L.) herbage post-partum (control), or harvested perennial ryegrass herbage both pre-partum and post-partum (GG). Prior to the experiment all cows were on a diet of pasture silage and maize silage.

Three weeks prior to their expected calving date, cows were randomly allocated to individual pens with separate feed boxes and all feed was offered ad libitum. Cows were penned adjacent to each other with both visual and tactile contact. Due to differences between expected and actual calving dates, the number of days for which treatments were imposed varied between cows. On average, treatment diets were fed for $11( \pm 7) \mathrm{d}$ pre-partum and for $14( \pm 0) \mathrm{d}$ post-partum. Pasture was harvested fresh daily using a selfpropelled mower and cart (Etesia, Wissembourg, France), and all feed was weighed and given in the morning at 10:30 h. Each cow had access to an extra-large feed bin containing their daily allocation and the bins were monitored throughout the day to ensure feed was always accessible. Extra harvested ryegrass was kept on hand in the event a top-up was needed. All refusals were collected, weighed and subsampled the next morning, prior to feeding. A mineral block (Welmin dry cow elite block; Agritech, Ballyanny, Ireland) was provided to each cow in their individual stalls, pre-partum, and was available ad libitum. Immediately following calving, all cows in the control treatment had their silage removed and replaced with harvested perennial ryegrass herbage, available ad libitum.

\section{Intake and nutritive characteristics}

The DM of all offered and refused feed was recorded for individual cows and the difference represented individual feed intakes. Daily, two subsamples of feed offered and refused were collected. An initial sample was oven-dried at $90^{\circ} \mathrm{C}$ for $16 \mathrm{~h}$ to determine $\mathrm{DM}$ concentration. The second subsample was frozen, freeze-dried, milled through a $0.5-\mathrm{mm}$ sieve and analysed at a commercial laboratory (Dairy One Forage Laboratory, Ithaca, NY, USA) for nutritive characteristics by wet chemistry (Association of Official Analytical Chemists, 2000). Averages for nutritive characteristics of the pasture silage and pasture offered during the experimental period are presented in Table 1. Diet Check (Heard et al., 2004) was used to evaluate the nutrient intake of the cows regarding energy and protein requirements.

The management of the swards followed the protocol described by Egan et al. (2018) for the Gr250 treatment.

\section{Milk yield and composition}

Following calving, milking took place twice daily at 07:00 $\mathrm{h}$ and 16:00 h. Individual milk yield $(\mathrm{kg})$ was recorded at each milking (Dairymaster, Causeway, Co. Kerry, Ireland). Milk samples were taken at every milking and composition (fat, protein and lactose) was determined by automated infrared analysis using a Milkoscan 203 (Foss Electric, Hillerød, Denmark). Energy-corrected milk (ECM) yield was calculated using the following formula (Tyrrell \& Reid, 1965):

$$
\begin{aligned}
\operatorname{ECM}(\mathrm{kg})= & \text { milk yield }(\mathrm{kg}) \times[376 \times \text { fat }(\%) \\
& +209 \times \text { protein }(\%)+948] / 3,138
\end{aligned}
$$


Table 1: Nutritive characteristics of feed offered during the experimental period

\begin{tabular}{lcccc}
\hline & Silage & s.e. & $\begin{array}{c}\text { Perennial } \\
\text { ryegrass } \\
\text { herbage }\end{array}$ & s.e. \\
\hline Crude protein & 130 & 4.1 & 252 & 3.5 \\
Neutral detergent fibre & 545 & 19.5 & 432 & 4.1 \\
Acid detergent fibre & 330 & 8.0 & 248 & 4.3 \\
Non-fibre carbohydrates & 203 & 19.7 & 191 & 5.8 \\
Total digestible nutrients & 670 & 4.1 & 702 & 1.0 \\
Dry matter digestibility (\%) & 63 & 0.6 & 70 & 0.6 \\
Metabolisable energy & 11 & 0.03 & 12 & 0.09 \\
(MJ/kg DM) & & & & \\
\hline
\end{tabular}

All values are presented as $\mathrm{g} / \mathrm{kg}$ DM unless otherwise indicated. $\mathrm{DM}=$ dry matter.

\section{Live weight and body condition score}

Cows were weighed once per week before the morning feed, which was post-milking if lactating. Weights were recorded electronically using a portable weighing scale and the Winweigh software package (Tru-Test Limited, Auckland, New Zealand). At the same time as weighing, all cows were condition scored by two trained assessors, using a scale of 0-5 (Lowman et al., 1976).

\section{Eating behaviour}

Two weeks prior to their expected calving date, cows were fitted with halters containing pressure and movement sensors (RumiWatch, Itin + Hoch $\mathrm{GmbH}$, Liestal, Switzerland) to quantify daily ruminating and eating time. The halters remained on the cows until $14 \mathrm{~d}$ post-partum.

\section{Blood samples}

The target day and the actual day of blood sampling relative to parturition for the GG and the control treatment groups were -14 and -13.6 (s.d. 2.12, $n=10$ ), -7 and -7.2 (s.d. 2.20, $n=13$ ), 0 and 0 (s.d. $0.00, n=13$ ), 7 and 6.8 (s.d. 0.43, $n=13$ ) and 14 and 14.1 (s.d. $0.51, n=13$ ), respectively. Blood samples were collected via the coccygeal vein using evacuated tubes containing lithium heparin (Becton Dickinson, Plymouth, UK) and immediately put on ice. Within $15 \mathrm{~min}$ of collection, samples were centrifuged (Kontron Centrikon T-324, Kontron Instruments, Milan, Italy) at $530 \mathrm{~g}$ for $15 \mathrm{~min}$ at $4^{\circ} \mathrm{C}$. The plasma was collected and stored at $-20^{\circ} \mathrm{C}$ until analyses. Nonesterified fatty acids (NEFAs), glucose, $\beta$-hydroxybutyrate (BHBA) and creatinine concentrations were analysed by enzymatic colourimetry using an ABX Pentra 400 autoanalyser (ABX Mira, Montpelier, France; BHBA and creatinine kits were supplied by Randox Laboratories Ltd., Crumlin, UK; NEFA kit supplied by Wako Chemicals $\mathrm{GmbH}$, Neuss, Germany; glucose kit supplied by Horiba BAX, Montpellier, France). Plasma urea concentrations were measured using an enzymatic kinetic method (Randox Laboratories, Ltd., Crumlin, UK) on a Randox RX Imola multichannel autoanalyser (Randox Laboratories, Ltd., Crumlin, UK).

\section{Statistical analyses}

One cow was removed from the control treatment due to low intakes during the initial $2 \mathrm{~d}$. All data were analysed using Genstat for Windows (Genstat 18th edition, VSN International Ltd., Hemel Hempstead, UK). An average DMI, estimated metabolisable energy (ME) balance, crude protein (CP) balance, metabolic live weight (MLW) and DMI as a proportion of MLW were calculated for each cow pre- and post-partum. These values were then subjected to an analysis of variance (ANOVA) with the factorial treatment structure of treatment by stage (pre- or post-partum) and treatment blocking structure of cow split for stage. Due to the inconsistencies in milk composition when transitioning from colostrum to the early lactation period (Tsioulpas et al., 2007), milk production data were refined to only include days 5 through 14 . Using daily DMI and ECM, an individual feed conversion efficiency (FCE) was calculated for each cow on days 5 through 14 (postpartum). Additionally, a corrected FCE value was calculated following the methodology of Beever \& Doyle (2007). Milk production and FCE data were then analysed using ANOVA with treatment used as a single factor in the treatment structure and a blocking structure of cow split for day relative to calving. Behaviour data were summarised daily for each cow as minutes spent eating, ruminating and not chewing. The data were then analysed using a mixed-effects model, with the random effects cow split for day relative to calving. The factorial fixed effects for the model were treatment by stage (pre- or post-partum). Blood samples were categorised by stage as either pre-partum, at calving or post-partum and within stage by day relative to calving. Plasma metabolite data were then analysed by ANOVA with a factorial treatment structure of treatment by stage (pre-partum, at calving or post-partum) split for day relative to calving, and a blocking structure of cow split for day relative to calving.

\section{Results}

Intake, live weight, body condition score and eating behaviour

Mean DMI, live weight, BCS, DMI as a proportion of MLW, nutrient balance information and eating behaviour of cows fed according to each of the treatments are presented in Table 2. Daily DMI for each treatment group is presented in Figure 1. 
Table 2: Mean DMI, DMI as a proportion of metabolic live weight, BCS, eating behaviour and nutrient balances of cows fed according to each of the treatments

\begin{tabular}{|c|c|c|c|c|c|c|c|c|}
\hline & \multicolumn{2}{|c|}{ Control } & \multicolumn{2}{|c|}{ GG } & \multirow[b]{2}{*}{ s.e.d. } & \multicolumn{3}{|c|}{$P$ value } \\
\hline & Pre & Post & Pre & Post & & Treatment & Stage & Interaction \\
\hline DMI (kg/cow per day) & 5.6 & 8.6 & 6.3 & 9.0 & 0.26 & 0.571 & $<0.001$ & 0.339 \\
\hline DMI (g/kg live weight ${ }^{0.75}$ per day) & 52.6 & 88.5 & 58.3 & 90.8 & 4.32 & 0.768 & $<0.001$ & 0.403 \\
\hline Live weight (kg) & 501 & 446 & 523 & 445 & 24.0 & 0.521 & $<0.001$ & 0.264 \\
\hline $\mathrm{BCS}^{1}$ & 3.30 & 3.00 & 3.30 & 3.10 & 0.050 & 0.516 & $<0.001$ & 0.448 \\
\hline Eating (min/cow per day) & 400 & 374 & 420 & 389 & 6.1 & 0.222 & $<0.001$ & 0.737 \\
\hline Ruminating (min/cow per day) & $503^{a}$ & $463^{\text {bc }}$ & $449^{b}$ & $470^{\mathrm{ac}}$ & 29.7 & 0.904 & 0.985 & 0.030 \\
\hline Not chewing (min/cow per day) & 540 & 599 & 567 & 576 & 33.0 & 0.626 & 0.110 & 0.146 \\
\hline Intake rate (kg DM/cow per hour) & 0.6 & 0.9 & 0.8 & 1.0 & 0.09 & 0.672 & $<0.001$ & 0.228 \\
\hline \multicolumn{9}{|l|}{ Estimated ME (MJ/cow per day) } \\
\hline Required & 94 & 118 & 93 & 130 & 7.2 & 0.351 & $<0.001$ & 0.252 \\
\hline Consumed & 60 & 101 & 74 & 106 & 5.01 & 0.189 & $<0.001$ & 0.248 \\
\hline Excess/deficit & -34 & -17 & -19 & -24 & 7.6 & 0.565 & 0.387 & 0.109 \\
\hline \multicolumn{9}{|l|}{ CP (g/cow per day) } \\
\hline Required & 657 & 1,550 & 742 & 1,631 & 71.1 & 0.378 & $<0.001$ & 0.964 \\
\hline Consumed & $712^{\mathrm{a}}$ & $2,094^{b}$ & $1,546^{c}$ & $2,203^{b}$ & 87.1 & 0.007 & $<0.001$ & $<0.001$ \\
\hline Excess/deficit & $55^{\mathrm{a}}$ & $545^{\mathrm{b}}$ & $804^{c}$ & $573^{b}$ & 32.7 & $<0.001$ & 0.001 & $<0.001$ \\
\hline
\end{tabular}

Control, cows offered ad libitum silage pre-partum and offered ad libitum perennial ryegrass herbage post-partum; GG, cows offered ad libitum perennial ryegrass herbage pre- and post-partum.

Means within rows followed by different letters are significantly different at $P=0.05$.

${ }^{1} 0-5$ scale.

$\mathrm{BCS}=$ body condition score, $\mathrm{CP}=$ crude protein, $\mathrm{DMI}=$ dry matter intake, $\mathrm{ME}=$ metabolisable energy .

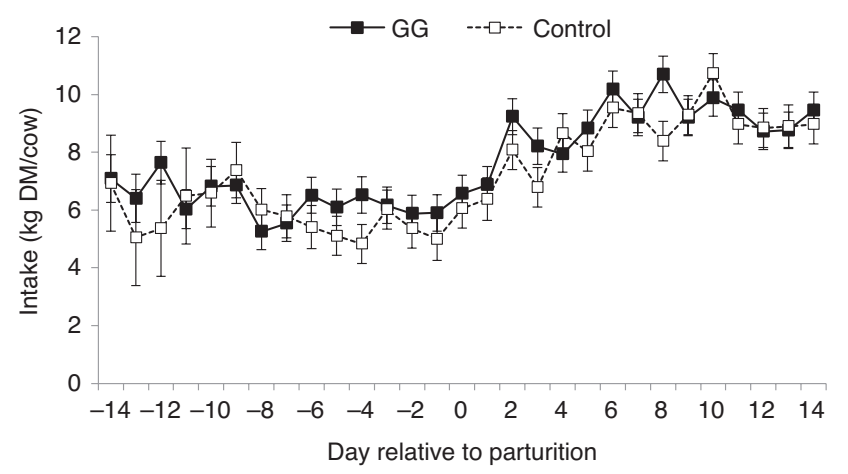

Figure 1. Mean dry matter intakes during the transition period for cows offered either grass silage pre-partum and perennial ryegrass herbage post-partum (control - $\square$ ) or perennial ryegrass herbage both pre- and post-partum ( $G G-\mathbf{m})$. Error bars represent standard errors of means.

There was no difference between the DMI of the treatment groups, pre- or post-partum. The post-partum DMI was, on average, $2.9 \mathrm{~kg} \mathrm{DM} / \mathrm{cow}$ per day greater than pre-partum
DMI. The heifers were consuming an average of $1.2 \%$ of their live weight as DMI pre-partum and $2.0 \%$ post-partum, with no differences between treatments. There were no differences in BCS between treatments, which declined by 0.25 units following parturition. Live weight did not differ between treatments pre- or post-partum, averaging $512 \mathrm{~kg}$ and $446 \mathrm{~kg}$, respectively. An interaction effect between treatment and stage (pre- or post-partum) occurred for time spent ruminating. The amount of time spent ruminating decreased following calving for the control cows but increased for the GG cows.

There were no differences in ME required or consumed between the treatments. Requirements increased post-partum and were met by an increase in ME consumed. Despite the increased intake, the cows were in deficit both pre- and post-partum with no difference between the two, averaging $23 \mathrm{MJ} /$ cow per day. There was however a tendency towards an interaction, such that control cows were in greater deficit pre-partum compared to post-partum while the deficiency in the GG treatment was similar at both stages. CP balance was affected by a treatment and stage interaction. Pre-partum, the GG treatment group was consuming $804 \mathrm{~g} / \mathrm{cow}$ per day more 
than the calculated requirements. The control cows, while still in excess, were consuming much lower quantities resulting in the consumption of $55 \mathrm{~g} / \mathrm{cow}$ per day more than required. While requirements of $\mathrm{CP}$ for both treatment groups increased post-partum, so did the total amount of CP consumed. This resulted in both treatment groups remaining in a positive balance, but there was no longer a difference between the two, due to a greater increase in amount consumed by the control group.

\section{Milk yield and composition}

Mean daily milk yield, ECM yield, milk composition, estimates of FCE and corrected FCE from cows fed according to each of the treatments are presented in Table 3. There were no differences between treatments for any of the parameters. Correcting the measured FCE for milk produced from tissue mobilisation resulted in lower FCE values for both treatments. The estimated amount of ECM produced from tissue mobilisation was not different between the treatments, nor was the amount produced from feed.

\section{Plasma metabolites}

Plasma NEFA, glucose, BHBA, urea and creatinine concentrations from days $-14,-7,0,7$ and 14 relative to parturition for both treatments are presented in Figure 2. An

Table 3: Mean daily milk yield, ECM yield, milk composition and estimates of FCE and corrected FCE from cows fed according to each of the treatments

\begin{tabular}{lcccc}
\hline & Control & GG & s.e.d. & $P$ value \\
\hline Milk yield (kg/cow per & 14.8 & 16.7 & 1.51 & 0.232 \\
day) & & & & \\
ECM (kg/cow per day) & 17.7 & 20.0 & 2.05 & 0.283 \\
Protein (\%) & 3.8 & 3.7 & 0.11 & 0.316 \\
Fat (\%) & 5.4 & 5.4 & 0.33 & 0.881 \\
Lactose (\%) & 4.6 & 4.6 & 0.07 & 0.426 \\
Calculated FCE & 2.0 & 2.2 & 0.24 & 0.459 \\
ECM from body tissue & 2.7 & 3.7 & 1.50 & 0.529 \\
(kg/cow per day) & & & & \\
ECM from feed & 15.0 & 16.4 & 1.32 & 0.331 \\
(kg/cow per day) & & & & \\
Corrected FCE & & 1.9 & 0.08 & 0.316 \\
\hline
\end{tabular}

Control, cows offered ad libitum silage pre-partum and offered ad libitum perennial ryegrass herbage post-partum; GG, cows offered ad libitum perennial ryegrass herbage pre- and post-partum. ${ }^{1} \mathrm{FCE}$ corrected for milk produced from tissue mobilisation (Beever \& Doyle, 2007).

$\mathrm{ECM}=$ energy-corrected milk, FCE = feed conversion efficiency. interaction between treatment and stage for circulating NEFA concentrations $(P=0.005)$ resulted in both treatments showing similar increases pre-partum and both continued to increase post-partum. However, the post-partum increase was more pronounced for the control cows. Both treatments reached a peak in NEFA concentrations at $7 \mathrm{~d}$ post-partum. An interaction between stage and day resulted in an increase between the first and the second sample pre-partum measurements but no difference between the two post-partum measurements. Plasma glucose concentrations were unaffected by treatment $(P=0.196)$ but were affected by stage $(P<0.001)$. While there was no difference in glucose concentrations between the pre- and post-partum samples, a peak occurred at parturition. There was a trend towards an effect of treatment on plasma BHBA concentrations $(P=0.099)$. The BHBA concentration in the plasma of the control cows increased steadily from day -14 to day 14 , with a significant difference between the first and the last measurement. There was no difference in the concentrations from the GG treatment group. Plasma BHBA was affected by stage $(P=0.023)$ with concentrations being the lowest pre-partum and the highest post-partum, but this was driven by the differences in the control group. A treatment by stage interaction for plasma urea $(P<0.001)$ resulted in significantly higher concentrations in GG cows prepartum and at calving. The concentration in the control cows increased post-partum, resulting in similar concentrations for the two treatment groups. Creatinine concentrations did not differ between treatments. Levels were similar in the prepartum and calving samples, then declined post-partum.

\section{Discussion}

Increasing DMI pre-partum can help improve metabolic parameters and decrease the incidences of metabolic disorders (Grummer, 1995). Under the conditions of the current experiment, early adaptation to perennial ryegrass herbage did not increase DMI pre-partum, nor did it increase DMI post-partum or result in milk production benefits. The intake pre-partum, $1.2 \%$ of their live weight as DMI and $2.0 \%$ postpartum, is similar to that reported for heifers in other transition experiments (Daniels et al., 2007; Janovick \& Drackley, 2010). The DMI of both the control and the GG group did increase with the onset of lactation by $35 \%$ and $30 \%$, respectively. An increase of this level is consistent with other reports of dairy cows in transition experiments (McNamara et al., 2003a; Douglas et al., 2006). The increase in DMl serves to boost energy intake and moderate the need for excessive lipid metabolism to meet the energy demands of lactation. The DMI was reflected in the BCS of the cows with no differences between the treatments, pre- or post-partum, and all were considered within an optimum range (Roche et al., 2009). 

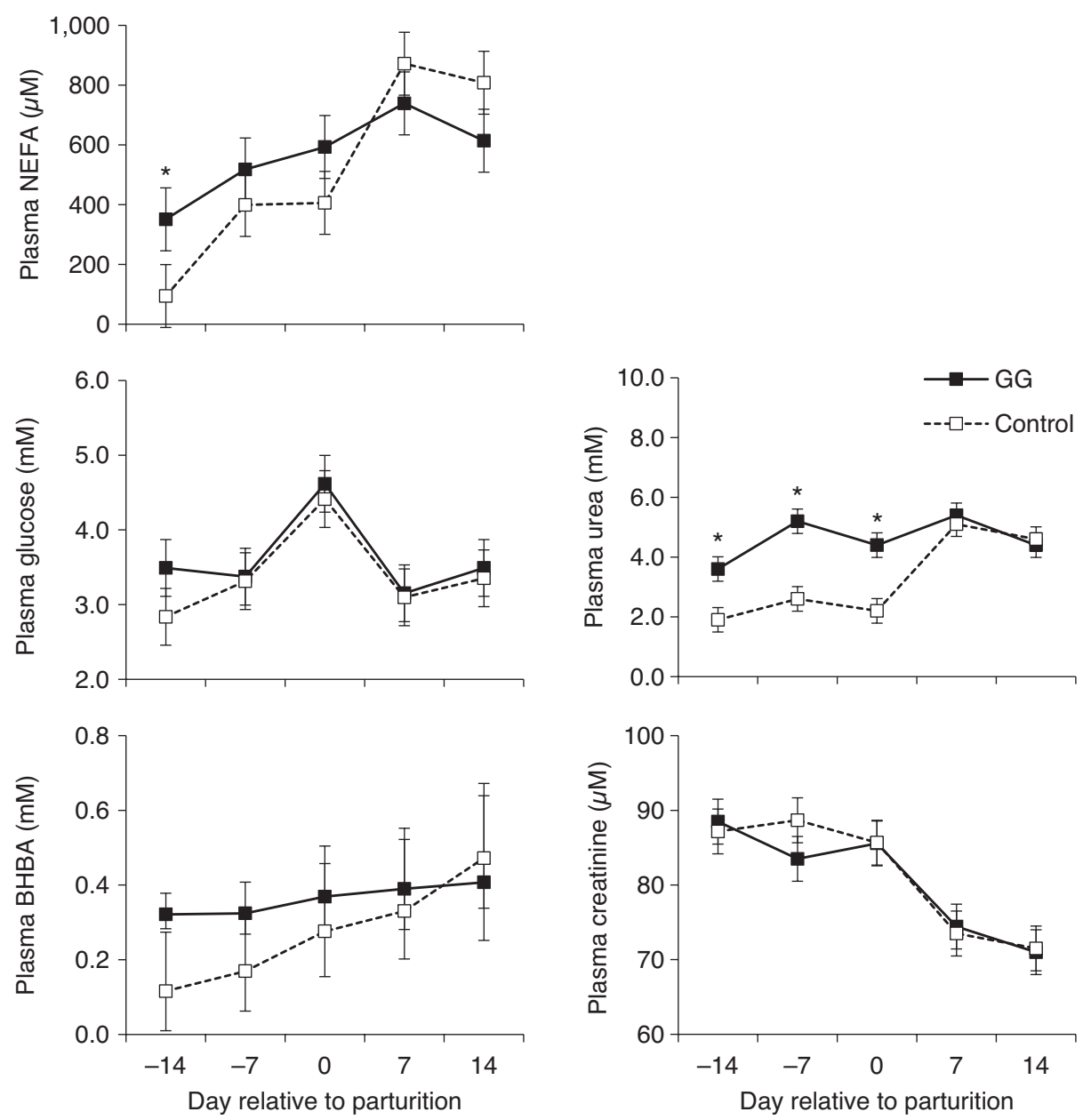

Figure 2. Mean circulating plasma metabolites during the transition period for cows offered either grass silage pre-partum and perennial ryegrass herbage post-partum (control $-\square$ ) or perennial ryegrass herbage both pre- and post-partum (GG - - ). Asterisks indicate a difference between treatments within day $(P<0.05)$. BHBA $=\beta$-hydroxybutyrate; NEFA $=$ non-esterified fatty acid.

The BCS of both treatment groups declined, as was expected. During the transition from late gestation to early lactation, it is typical for dairy cows to undergo a period of NEB, resulting in a decline in BCS (Grummer, 1995; Drackley, 1999). The energy deficits reported for both treatments are similar to those reported in other transition experiments (Beam \& Butler, 1998; Vandehaar et al., 1999). McNamara et al. (2003b) fed cows only high-quality silage pre-partum and also found them to be in NEB in the final weeks of gestation. While the requirements for ME increased post-partum, so did DMI, negating some of the deficit. However, body reserves were still being mobilised as milk production needs were not being met by intake alone. As the early lactation cows were in NEB, the measured FCE was overestimated due to the contribution of tissue mobilisation to milk production (Beever \& Doyle, 2007). The corrected FCE, which adjusts for this, was much lower and there was no difference between treatments, indicating an equal level of tissue mobilisation and that the GG cows were no better supported for beginning lactation and demonstrated no obvious benefits from early perennial ryegrass adaptation. Counterproductively, consuming perennial ryegrass herbage pre-partum may have actually been costing the GG cows energy. As the perennial ryegrass herbage was providing $\mathrm{CP}$ in excess of requirements, energy was likely being used to metabolise the extra protein and synthesise and excrete urea (Reed et al., 2017). The significantly higher plasma urea from the GG cows pre-partum and at parturition is indicative of high CP in the diet (Butler, 1998). This is somewhat supported further by the plasma NEFA and BHBA concentrations being marginally higher pre-partum for GG cows indicating increased nutritional stress from a metabolic perspective, despite DMI and ME intakes being similar. The pattern of decreasing plasma creatinine concentrations post-partum and the concentrations reported for both treatment groups 
in the current experiment are similar to those reported in other transition experiments (Piccione et al., 2012) and are considered within the normal range for lactating dairy cows (Cozzi et al., 2011).

The hormonal changes in the lead up to parturition, namely to catecholamines and glucocorticoids, result in a dramatic increase in the rate of gluconeogenesis and glycogenesis (Vazquez-Anon et al., 1994; Drackley et al., 2001). This results in a peak in plasma glucose concentration at parturition, as seen in both treatments in the current experiment. The reduction in these circulating glucocorticoids and the demand for glucose with the onset of milk synthesis then resulted in plasma glucose concentrations declining rapidly postpartum. Despite the abrupt changes in circulating glucose concentrations within the current experiment, they are considered within the normal range for dairy cows (Cozzi et al., 2011). As available glucose decreases at parturition, the body responds by increasing lipolysis, releasing NEFA into the bloodstream to meet the energy needs of the dairy cow (McNamara, 1991). Circulating NEFA concentrations are regularly used as a proxy for energy balance; higher NEFA levels indicate a greater degree of NEB. It is typical for the levels of circulating NEFA to increase as parturition approaches (Bell, 1995) and continue into early lactation as the animal enters a state of NEB. Within the current experiment, DMI declined slightly in the lead up to parturition (Figure 1), a time when energy demands are heightened, and so lipolysis increased to meet the energy shortfall (McNamara, 1991; Bertics et al., 1992). Additionally, it has previously been reported that as cows progress from late gestation to early lactation, plasma insulin levels decline (Adewuyi et al., 2005). This combination of factors resulted in a peak in NEFA concentrations within the current experiment at $7 \mathrm{~d}$ post-partum. Concentrations of serum NEFA $>500 \mu \mathrm{M}$ pre-partum are linked to post-partum health issues, as are post-partum levels $>1,000 \mu \mathrm{M}$ (McArt et al., 2013). The NEFA concentrations within the current experiment were all below these thresholds but were still high, perhaps exacerbated by the withholding of concentrates (Petterson et al., 1994), an important source of energy for higher-producing dairy cows in early lactation. When the liver can no longer increase the amount of NEFA being oxidised and concentrations of stored triacylglycerol are exceeded, the concentration of circulating ketones increases. ABHBA threshold of $1.2 \mathrm{mmol} / \mathrm{L}$ is typically used to identify cows with excessive amounts of circulating ketones post-partum (McArt et al., 2013). The concentrations measured within the current experiment were well below this threshold, indicating the cows were not in excessive NEB and adequately adapting to lactation.

Despite both treatment groups eating more post-partum, time spent eating actually decreased with cows increasing their intake rates instead. This is likely a combination of lactation increasing the drive to eat and the temporary fasting imposed through milking increasing subsequent intake rates (Kennedy et al., 2009). The control cows spent more time ruminating pre-partum, likely driven by the greater neutral detergent fibre concentration in the silage (Beauchemin \& Yang, 2005). There were no differences in rumination time post-partum once all cows were consuming the same feed.

While there were some numerical differences in the production outcomes and the energy balance pre-partum, they were not statistically significant, possibly due to low cow numbers per treatment. To be statistically significant at the $5 \%$ level in our experiment, effects needed to be as large as DMI $0.57 \mathrm{~kg} / \mathrm{cow}$ per day, milk yield $3.32 \mathrm{~kg} / \mathrm{cow}$ per day, ECM $4.5 \mathrm{~kg} / \mathrm{cow}$ per day or calculated FCE 0.53 (corrected FCE 0.18). Additionally, the experiment was conducted with first-lactation cows which may not be representative of higher parity cows in that their response to improved nutrition may have improved growth rates rather than increased milk yield. However, this research provides support for a pasture utilisation method that allows the feeding of fresh herbage when conventional grazing is not possible. Previous research has highlighted the benefits of zero-grazing, a management technique during which cows are housed indoors and offered fresh cut herbage. Zero-grazing of low herbage mass swards improves pasture utilisation, while maintaining DMI and milk production (Dohme-Meier et al., 2014; McConnell et al., 2018; Holohan et al., 2020). The pre-partum feeding of cut herbage, as conducted in the current experiment, could be a strategy to optimise pasture utilisation on Irish dairy farms.

\section{Conclusion}

Under the conditions of this experiment adapting first-lactation dairy cows to perennial ryegrass prior to parturition did not improve DMI or milk yield, showing no benefit over current feeding strategies. It is possible that the similarities between the forages mean that a change from pasture silage to perennial ryegrass herbage post-partum does not disrupt normal rumen function and hence no early adaptation to perennial ryegrass is required, indicating that current feeding strategies are adequate in terms of a successful dietary changeover.

\section{Acknowledgements}

The authors are grateful to the technical and farm staff at Teagasc Moorepark for their assistance throughout the experiment. This research was funded by Teagasc, Agriculture Victoria Research, Dairy Australia and The University of Melbourne. 


\section{References}

Adewuyi, A.A., Gruys, E. and Van Eerdenburg, F.J.C.M. 2005. Non esterified fatty acids (NEFA) in dairy cattle. A review. Veterinary Quarterly 27: 117-126.

Association of Official Analytical Chemists. 2000. "Official Methods of Analysis of AOAC International." 17th Edition. AOAC International Gaithersburg, MD, USA.

Bauman, D.E. and Currie, W.B. 1980. Partitioning of nutrients during pregnancy and lactation: a review of mechanisms involving homeostasis and homeorhesis. Journal of Dairy Science 63: 1514-1529.

Beam, S.W. and Butler, W.R. 1998. Energy balance, metabolic hormones, and early postpartum follicular development in dairy cows fed prilled lipid. Journal of Dairy Science 81: 121-131.

Beauchemin, K.A. and Yang, W.Z. 2005. Effects of physically effective fiber on intake, chewing activity, and ruminal acidosis for dairy cows fed diets based on corn silage. Journal of Dairy Science $\mathbf{8 8}$ : 2117-2129.

Beever, D.E. and Doyle, P.T. 2007. Feed conversion efficiency as a key determinant of dairy herd performance: a review. Australian Journal of Experimental Agriculture 47: 645-657.

Bell, A.W. 1995. Regulation of organic nutrient metabolism during transition from late pregnancy to early lactation. Journal of Animal Science 73: 2804-2819.

Bertics, S.J., Grummer, R.R., Cadorniga-Valino, C. and Stoddard, E.E. 1992. Effect of prepartum dry matter intake on liver triglyceride concentration and early lactation. Journal of Dairy Science 75 : 1914-1922.

Butler, W.R. 1998. Effect of protein nutrition on ovarian and uterine physiology in dairy cattle. Journal of Dairy Science 81: 2533-2539.

Cozzi, G., Ravarotto, L., Gottardo, F., Stefani, A.L., Contiero, B., Moro, L., Brscic, M. and Dalvit, P. 2011. Reference values for blood parameters in Holstein dairy cows: effects of parity, stage of lactation, and season of production. Journal of Dairy Science 94: 3895-3901.

Curtis, C.R., Erb, H.N., Sniffen, C.J., Smith, R.D. and Kronfeld, D.S. 1985. Path analysis of dry period nutrition, postpartum metabolic and reproductive disorders, and mastitis in Holstein cows. Journal of Dairy Science 68: 2347-2360.

Daniels, K.J., Donkin, S.S., Eicher, S.D., Pajor, E.A. and Schutz, M.M. 2007. Prepartum milking of heifers influences future production and health. Journal of Dairy Science 90: 2293-2301.

Dillon, P., Crosse, S., O'Brien, B. and Mayes, R.W. 2002. The effect of forage type and level of concentrate supplementation on the performance of spring-calving dairy cows in early lactation. Grass and Forage Science 57: 212-223.

Dillon, P., Crosse, S., Stakelum, G. and Flynn, F. 1995. The effect of calving date and stocking rate on the performance of springcalving dairy cows. Grass and Forage Science 50: 286-299.
Dohme-Meier, F., Kaufmann, L.D., Görs, S., Junghans, P., Metges, C.C., Van Dorland, H.A., Bruckmaier, R.M. and Münger, A. 2014. Comparison of energy expenditure, eating pattern and physical activity of grazing and zero-grazing dairy cows at different time points during lactation. Livestock Science 162: 86-96.

Douglas, G.N., Overton, T.R., Bateman, H.G., Dann, H.M. and Drackley, J.K. 2006. Prepartal plane of nutrition, regardless of dietary energy source, affects periparturient metabolism and dry matter intake in Holstein cows. Journal of Dairy Science 89: 2141-2157.

Drackley, J.K. 1999. Biology of dairy cows during the transition period: the final frontier? Journal of Dairy Science 82: 2259-2273.

Drackley, J.K., Overton, T.R. and Douglas, G.N. 2001. Adaptations of glucose and long-chain fatty acid metabolism in liver of dairy cows during the periparturient period. Journal of Dairy Science $\mathbf{8 4}$ : E100-E112.

Egan, M., Galvin, N. and Hennessy, D. 2018. Incorporating white clover (Trifolium repens L.) into perennial ryegrass (Lolium perenne L.) swards receiving varying levels of nitrogen fertilizer: effects on milk and herbage production. Journal of Dairy Science 101: 3412-3427.

Finneran, E., Crosson, P., O'Kiely, P., Shalloo, L., Forristal, D. and Wallace, M. 2010. Simulation modelling of the cost of producing and utilising feeds for ruminants on Irish farms. Journal of Farm Management 14: 95-116.

Grummer, R.R. 1995. Impact of changes in organic nutrient metabolism on feeding the transition dairy cow. Journal of Animal Science 73: 2820-2833.

Grummer, R.R., Mashek, D.G. and Hayirli, A. 2004. Dry matter intake and energy balance in the transition period. Veterinary Clinics of North America: Food Animal Practice 20: 447-470.

Grummer, R.R., Wiltbank, M.C., Fricke, P.M., Watters, R.D. and Silva-Del-Rio, N. 2010. Management of dry and transition cows to improve energy balance and reproduction. Journal of Reproduction and Development 56: S22-S28.

Hanrahan, L., McHugh, N., Hennessy, T., Moran, B., Kearney, R., Wallace, M. and Shalloo, L. 2018. Factors associated with profitability in pasture-based systems of milk production. Journal of Dairy Science 101: 5474-5485.

Heard, J.W., Cohen, D.C., Doyle, P.T., Wales, W.J. and Stockdale, C.R. 2004. Diet Check—a tactical decision support tool for feeding decisions with grazing dairy cows. Animal Feed Science and Technology 112: 177-194.

Holohan, C., Mulligan, F.J., Somers, J., Pierce, K.M. and Lynch, M.B. 2020. Zero-grazing versus conventional grazing in early lactation autumn-calving dairy cows in Ireland. Proceedings of the Meeting the future demands for grassland production, Helsinki, Finland, page 273.

Horan, B., Mee, J.F., Rath, M., O'Connor, P. and Dillon, P. 2005. Effect of strain of Holstein-Friesian cow and feed system on reproductive performance in seasonal-calving milk production systems over four years. Animal Science 79: 453-468. 
Humer, E., Petri, R.M., Aschenbach, J.R., Bradford, B.J., Penner, G.B., Tafaj, M., Südekum, K.-H. and Zebeli, Q. 2018. Invited review: Practical feeding management recommendations to mitigate the risk of subacute ruminal acidosis in dairy cattle. Journal of Dairy Science 101: 872-888.

Janovick, N.A. and Drackley, J.K. 2010. Prepartum dietary management of energy intake affects postpartum intake and lactation performance by primiparous and multiparous Holstein cows. Journal of Dairy Science 93: 3086-3102.

Kaufmann, W., Hagemeister, H. and Dirksen, G. 1980. Adaptation to changes in dietary composition, level and frequency of feeding. In: "Digestive Physiology and Metabolism in Ruminants" (eds. Y. Ruckebusch and P. Thivend), AVI Publishing Company, Westport, CT, pages 587-602.

Kennedy, E., McEvoy, M., Murphy, J. and O’Donovan, M. 2009. Effect of restricted access time to pasture on dairy cow milk production, grazing behavior, and dry matter intake. Journal of Dairy Science 92: 168-176.

Lowman, B.G., Scott, N. and Somerville, S.H. 1976. Condition scoring of cattle. Bulletin No 6, The East Scotland College of Agriculture, Animal Production, Advisory and Development Department, Edinburgh.

Mann, S., Yepes, F.A.L., Overton, T.R., Wakshlag, J.J., Lock, A.L., Ryan, C.M. and Nydam, D.V. 2015. Dry period plane of energy: effects on feed intake, energy balance, milk production, and composition in transition dairy cows. Journal of Dairy Science $\mathbf{9 8}$ : 3366-3382.

McArt, J.A.A., Nydam, D.V., Oetzel, G.R., Overton, T.R. and Ospina, P.A. 2013. Elevated non-esterified fatty acids and $\beta$ hydroxybutyrate and their association with transition dairy cow performance. The Veterinary Journal 198: 560-570.

McConnell, D.A., Scoley, G. and Gordon, A. 2018. Impact of precutting herbage mass on cow performance and sward utilisation in zero-grazing systems. Grassland Science in Europe 23: 99-101.

McNamara, J.P. 1991. Regulation of adipose tissue metabolism in support of lactation. Journal of Dairy Science 74: 706-719.

McNamara, S., O'Mara, F.P., Rath, M. and Murphy, J.J. 2003a. Effects of different transition diets on dry matter intake, milk production, and milk composition in dairy cows. Journal of Dairy Science $\mathbf{8 6}$ : 2397-2408.

McNamara, S., Murphy, J.J., Rath, M. and O'Mara, F.P. 2003b. Effects of different transition diets on energy balance, blood metabolites and reproductive performance in dairy cows. Livestock Production Science 84: 195-206.

Petterson, J.A., Slepetis, R., Ehrhardt, R.A., Dunshea, F.R. and Bell, A.W. 1994. Pregnancy but not moderate undernutrition attenuates insulin suppression of fat mobilization in sheep. The Journal of Nutrition 124: 2431-2436.

Piccione, G., Messina, V., Marafioti, S., Casella, S., Giannetto, C. and Fazio, F. 2012. Changes of some haematochemical parameters in dairy cows during late gestation, post partum, lactation and dry periods. Veterinarija Ir Zootechnika 58: 59-64.

Pourazad, P., Khiaosa-Ard, R., Qumar, M., Wetzels, S.U., Klevenhusen, F., Metzler-Zebeli, B.U. and Zebeli, Q. 2016. Transient feeding of a concentrate-rich diet increases the severity of subacute ruminal acidosis in dairy cattle. Journal of Animal Science 94: 726-738.

Reed, K.F., Bonfá, H.C., Dijkstra, J., Casper, D.P. and Kebreab, E. 2017. Estimating the energetic cost of feeding excess dietary nitrogen to dairy cows. Journal of Dairy Science 100: 7116-7126.

Roche, J.R., Friggens, N.C., Kay, J.K., Fisher, M.W., Stafford, K.J. and Berry, D.P. 2009. Invited review: Body condition score and its association with dairy cow productivity, health, and welfare. Journal of Dairy Science 92: 5769-5801.

Shanks, R.D., Freeman, A.E. and Dickinson, F.N. 1981. Postpartum distribution of costs and disorders of health. Journal of Dairy Science 64: 683-688.

Tremere, A.W., Merrill, W.G. and Loosli, J.K. 1968. Adaptation to high concentrate feeding as related to acidosis and digestive disturbances in dairy heifers. Journal of Dairy Science 51: 1065-1072.

Tsioulpas, A., Grandison, A.S. and Lewis, M.J. 2007. Changes in physical properties of bovine milk from the colostrum period to early lactation. Journal of Dairy Science 90: 5012-5017.

Tyrrell, H.F. and Reid, J.T. 1965. Prediction of the energy value of cow's milk. Journal of Dairy Science 48: 1215-1223.

Vandehaar, M.J., Yousif, G., Sharma, B.K., Herdt, T.H., Emery, R.S., Allen, M.S. and Liesman, J.S. 1999. Effect of energy and protein density of prepartum diets on fat and protein metabolism of dairy cattle in the periparturient period. Journal of Dairy Science $\mathbf{8 2}$ : 1282-1295.

Vazquez-Anon, M., Bertics, S., Luck, M., Grummer, R.R. and Pinheiro, J. 1994. Peripartum liver triglyceride and plasma metabolites in dairy cows. Journal of Dairy Science 77: 1521-1528. 